\title{
POSTAL SERVICE, TRANSPORT SERVICE, COURIER SERVICE - A FEW REMARKS IN THE CONTEXT OF THE POSTAL LAW ACT 2012
}

\section{DANIEL DĄBROWSKI}

University of Szczecin, Faculty of Management and Economics of Services, POLAND e-mail: daniel.dabrowski@usz.edu.pl
RECEIVED
6 November 2018
ACCEPTED
3 December 2018
JEL
CLASSIFICATION
$\mathrm{K} 12, \mathrm{~K} 15$
KEYWORDS
postal service, courier service, contract of carriage of goods, carrier's liability, transport service, contract for the provision of postal services
ABSTRACT

\begin{abstract}
In the article the author tries to indicate the criteria distinguishing the postal service from the transport service in the context of the Postal Law Act 2012. The author notes that the Postal Law Act 2012 does not exclude the possibility of transporting postal items (with the exception of items of correspondence) with the omission of the Postal Law Act 2012 regime. The carrier may choose the type of contract concluded in connection with a clearance an item for displacement. In the author's opinion, such regulation is inappropriate, as services concerning postal items (bearing the marking of an addressee and an address) should in each case be performed on the basis of a contract for the provision of postal services.
\end{abstract}

\section{Introduction}

The postal services market has undergone significant changes in recent years. Technological development has resulted in the creation of new forms of communication, significantly reducing the importance of items of correspondence. The same factor triggered an explosion of e-commerce and the increase in the number of items containing ordered goods. As a result, structural changes occur: the volume of traditional items is decreasing, 
which is compensated by the increase in the number of courier items (UKE, 2018, p. 6). These processes overlap with legal changes which ensure liberalisation of the postal services market in order to increase competition in this market. These phenomena force operators to adapt the operating strategy to the changing market conditions (UKE, 2018, p. 6).

The current Postal Law Act 2012 (PLA 2012) divides the postal services market into four segments: universal services, courier services, services within the scope of universal services and other postal services (UKE, 2018, pp. 8-9; Syp, 2018, article 2, margin note 9). Prior to the entry into force of this Act, a significant part of courier services did not belong to the postal services sector and were performed on the basis of transport law. Currently, the term "courier item" is defined in the Act and the service which involves this kind of item is a type of postal service. However, the relation between the postal service (including courier service) and the transport service is still not clear. The purpose of this article is to present this relation and to assess the accuracy of the exclusion of some services of transport of goods from the regime of the Postal Law Act 2012.

\section{The postal service in the light of the Postal Law Act 2012}

The Postal Law Act 2012 lays down the rules for conducting business activities consisting in the provision of postal services (postal activities). The concept of a postal service is defined in Article 2 (1) PLA 2012. According to this Article, "A postal service shall mean the performance on commercial basis, in domestic or cross-border traffic, of:

a) collectively or separately provided clearance, sorting, delivery of postal items and printed forms;

b) transport of letter items and printed forms, if provided collectively with at least one of the activities referred to in point 1 ;

c) sending postal items by electronic communications means, if at the stage of clearance, transport or delivery of information message they take a physical form of a letter item;

d) operation of points of exchange enabling the clearance and exchange of correspondence between entities using the service of these points;

e) handling postal money orders."

Traditional postal services are those described in points 1 and 2. Each of the activities specified in point 1 is a postal service, even if it is performed separately (Syp, 2018, article 2, margin note 10; Gaj, Laprus-Bałuka, Zaborowska, 2017, article 2, margin note 2). The mere transport of postal items and non-addressed printed forms is not a postal service. Only if the operator transporting this type of items collectively provides one of the activities referred to in point 1 , then the service performed by it is a postal service.

For the correct interpretation of the above-mentioned article, it is necessary to refer to the legal definitions of terms used in it. The Postal Law Act 2012 defines the terms "non-addressed printed form",1 "delivery"2 and

\footnotetext{
${ }^{1}$ Written or graphic information, copied by printing or similar techniques, presented on paper or other material used in printing, including books, catalogues, newspapers or periodicals, without indication of an addressee and an address (Article 3 (6) PLA 2012).

2 Handing over a postal item or payment of an amount specified in the postal money order to the addressee, and in cases defined under the law also to another person, or submission of a printed form in accordance with the contract for the provision of postal services (Article 3 (4) PLA 2012).
} 
"transport". ${ }^{3}$ The essential concept is "postal item". It means "an object bearing the marking of an addressee and an address, submitted for clearance or cleared by the postal operator in order to transport it and deliver to the addressee" (Article 3 (21) PLA 2012). This definition is based on two main elements. Firstly, an object has to bear the addressee's name and address. The lack of such markings causes that the object does not have the status of a postal item (it may possibly be a non-addressed printed form). Secondly, the object has to be submitted to clearance or cleared by the postal operator. The latter term means "an undertaking authorised to perform postal activities based on an entry in the register of postal operators" (Article 3 (12) PLA 2012).

When defining "postal activity", "postal service" and "postal operator", the legislator committed an error in the form of a vicious circle (circulus in definiendo). "Postal activities" are defined as activities related to postal items, "postal item" is an item cleared by the postal operator, and "postal operator" is an undertaking authorised to perform postal activities. Keeping strictly to this definition, it should be concluded that an entity which is not entered in the register of postal operators never performs postal activities, as the items cleared by it for transport and delivery are not postal items. ${ }^{4}$ However, as stated in Article 126 (1) (1) PLA 2012, the performance of postal activities without the required entry in the register is subject to a fine. This article would be superfluous if it were assumed that "postal activities" are only activities performed by an authorised postal operator. For the purposes of the definition of the term "postal activities" it has to be assumed that these are activities referred to in Article 2 (1) PLA 2012 even if performed by an entity which does not formally have the status of a postal operator. Only such an assumption allows a consistent and rational result to be achieved in the interpretation of the provisions in question. It requires a deviation from the meaning of "postal item" as indicated by the legal definition. Such a deviation is considered inadmissible in the literature if it concerns the definition which is "univocally formulated" (Radwański, Zieliński, 2012, p. 531). The existence of a vicious circle while creating legal definition is sufficient justification for such a deviation.

Postal services for clients are performed on the basis on contracts for the provision of postal services concluded between senders and postal operators (Article 14 (1) PLA 2012). The Postal Law Act 2012 specifies, among others the manner of concluding such a contract, the grounds for refusal to conclude it and the possibility of unilateral change of the contract. The provisions regulating the liability of the postal operator for non-performance or improper performance of postal services are of great importance. As a rule, the provisions of the Civil Code apply to the postal operator's liability (Article 87 (1) PLA 2012), however, chapter 8 of the Postal Law Act 2012 provides for specific rules of this liability. The liability for non-performance or improper performance of universal services and the liability for non-performance or improper performance of other postal services are regulated in a different way.

\section{Carpiage of yoods performed "under separate provisions" as an activity which is not a postal service}

Article 2 (2) PLA 2012 provides for a list of activities which are not treated as postal services. Pursuant to the second point of this Article "carriage of goods other than correspondence, performed under separate provisions" is not a postal service. This exclusion raises many doubts.

It should be assumed that Article 2 (2) PLA 2012 includes types of services which, if they were not excluded in this Article, would be postal services. The inclusion of the carriage of goods in this provision therefore seems to

\footnotetext{
${ }^{3}$ Carriage of postal items, non-addressed printed forms and postal money orders using any means of transport (Article 3 (17) PLA 2012).

${ }^{4}$ Possibly, he would provide postal services in a situation where he would clear and deliver non-addressed printed forms. Such postal activity, however, does not require an entry in the registry of postal operators (Article 6 (2) PLA 2012.
} 
be a misunderstanding. In the light of Article 2 (1) (2) PLA 2012 the carriage of goods (referred to in this Article as "transport") if provided separately is not a postal service. Carriage of goods is a postal service only if it is provided collectively with at least one of the activities referred to in Article 2 (1) (1) PLA 2012. It seems that the intention of the legislator was to exclude the carriage of goods performed under separate provisions from the scope of the term "postal service", despite the performance of this carriage collectively with any of the activities indicated in Article (2) (1) (1) PLA 2012. This is also how this article is to be interpreted.

The article in question refers to the carriage of "goods". There is no doubt that this term refers to postal items ${ }^{5}$ and non-addressed printed forms. The activities performed in relation to goods other than postal items and nonaddressed printed forms are not, after all, postal services.

The above considerations lead to the conclusion that the carriage of postal items and non-addressed printed forms, performed collectively with at least one of the services referred to in Article 2 (1) (1) PLA 2012 is not a postal service, if it is performed "under separate provisions". The main problem lies in resolving to which "separate provisions" the reference is made to in Article 2 (2) (2) PLA 2012.

The literature indicates that separate provisions are, for example, the provisions of the Transport Law Act or the Aviation Law Act (Syp, 2018, article 2, margin note 17; Gaj, Laprus-Bałuka, Zaborowska, 2017, article 2, margin note 3). Similar views were expressed in the context of the Postal Law Act of 2003 (PLA 2003). Following this, one could also point, for example, to the provisions of the Civil Code and the international transport conventions. However, how to distinguish a carriage performed "under separate provisions" from a carriage performed under the provisions of Postal Law Act 2012? In principle, the will of the parties is decisive in this respect. If the parties agree to conclude a contract of carriage, it is not possible to recognise that a contract of a different kind has been concluded. In practice, it is a carrier who decides on the legal qualification of the contract, because it is also him who prepares a standard contract which his contractor only accepts. It should be added that the classification of a contract as a contract of carriage does not depend on whether a consignment note has been issued. In all legal acts regulating a contract of carriage, a consignment note is an optional document, the lack or irregularity of which does not affect the validity of the contract.

It is not difficult to notice that the exception provides for Article 2 (2) (2) PLA 2012 gives a very large leeway to entities which intend to provide services of the nature of postal services and at the same time do not want to be subject to the regime Postal Law Act 2012. To avoid application of Postal Law Act 2012 it is sufficient to choose an appropriate regime for the carriage of goods. The regulation of the Postal Law Act 2012 in this respect should be assessed negatively, as it creates an easy possibility of circumventing the Act.

It should be added that the above interpretation is not precluded by the content of Article 35 (1a) Transport Law Act 1984. According to this provision "A postal item which is the subject of a postal service within the meaning of the Postal Law Act 2012 shall not be considered to be a freight shipment". This provision requires that the postal item (and therefore the item cleared by the postal operator) should be "the subject of a postal service". However, these are the parties who decide whether the item is a subject of a contract of carriage or of a postal service.

${ }^{5}$ Within the meaning of Article 3 (21) PLA 2012 but omitting the element of clearance of an item by the postal operator. 


\section{Courier services}

The concept of courier item is defined in Article 3 (19) PLA 2012. According to this Article, a courier item means "a letter item which is a recorded item or a postal parcel cleared, sorted, transported and delivered in a manner that collectively guarantees:

a) direct collection of a postal item from the sender;

b) tracking a postal item from posting to delivery;

c) delivery of a postal item within a guaranteed time limit specified in the rules and regulations for the provision of postal services or in contracts for the provision of postal services;

d) delivery of a postal item directly to the addressee or to a person authorised to collect it;

e) obtaining an acknowledgement of receipt of a postal item in a written or electronic form".

The cited definition shows that the courier item can be a letter (recorded) ${ }^{6}$ or a postal parcel. ${ }^{7}$ In any case, a courier item is a postal item. The kind of the item is the first element of the definition of "courier item". The other two elements are: (1) the way of handling of the item (clearance, sorting, transport and delivery) and (2) the guarantee of performance specific services collectively (these services are listed above in points (a)-(e)) (Syp, 2018, article 3 , margin note 81).

The Postal Law Act 2012 does not define the term "courier service". It can be assumed that, in the strict sense, the courier service is the activities performed by the postal operator consisting in clearance, sorting, transport and delivery a recorded item or a postal parcel in the manner specified in Article 3 (19) PLA 2012. In order for recognition a service as a courier service, it is sufficient that the postal operator undertakes to perform activities related to the item in the manner specified in Article 3 (19) PLA 2012. However, it is not a requirement that in a particular case these activities are performed in this manner. It would be difficult to accept that the nature of the service is determined by whether it has been properly performed.

It should be stressed that the concept of "courier service" presented above is a narrow one. In practice, the term is often used in a broader sense, for example, it also refers to items which do not meet the requirements of a postal parcel (e.g. exceeding the weight or dimensions of a postal parcel) or when the postal operator does not provide all the services referred to in Article 3 (19) PLA 2012. Some courier companies broaden their offer and deliver various types of groupage cargo, thus becoming a competitor to traditional logistic enterprises (Marcysiak, Pieniak-Lendzion, Lendzion, 2013, p. 31).

In the explanatory memorandum of the Postal Law Act 2012, ${ }^{8}$ it was indicated that the definition of courier item was introduced in order to separate the segment of courier services "due to the exemption of operators providing this type of services from the obligation to participate in the financing of universal services from revenues generated

6 The letter item should be understood as "an item of correspondence or a printed form, excluding direct mail" (Article 3 (20) PLA 2012). An item of correspondence is a postal item other than a printed form containing information stored on any carrier, including information in embossed type (Article 3 (25) PLA 2012). "Form" should be understood as "a postal item with written or graphic information, copied by printing or similar techniques, presented on paper or other material used in printing, including books, catalogues, newspapers or periodicals" (Article 3 (5) PLA 2012). An item is recorded item if it is cleared with an acknowledgement of clearance and delivered with acknowledgement of receipt (Article 3 (23) PLA 2012).

${ }^{7}$ A postal parcel should be understood as "a recorded postal item other than a letter item, weighing up to $20,000 \mathrm{~g}$ and dimensions: a) of which none may exceed $2,000 \mathrm{~mm}$ or b) which may not exceed 3,000 $\mathrm{mm}$ for the sum of length and the largest perimeter measured in a different direction than length" (Article 3 (14) PLA 2012).

${ }^{8}$ See http://orka.sejm.gov.pl/Druki7ka.nsf/0/93D8A8EAC71F3371C1257A980048476D/\%24File/801.pdf (14/11/2018). 
from courier services". This purpose of introducing the definition in question is also emphasized in the literature (Stolarczyk, 2014, p. 76; Syp, 2018, article 3, margin note 80; Gaj, Laprus-Bałuka, Zaborowska, 2017, article 3, margin note 20). Before the entry into force of the Postal Law Act 2012, the concepts of courier item and courier services did not have their legal definition. ${ }^{9}$ There was also no agreement on the criteria for distinguishing such services and the applicable legal regime. The prevailing view was about two specific types of courier services. If the item carried by the courier company contained correspondence, then it was assumed that the service performed is a postal service, to which the provisions of the Postal Law Act 2003 applied. ${ }^{10}$ Consequently, the contract concluded between the parties was considered to be a contract for the provision of postal services. The carriage of goods other than correspondence by a courier company was considered to be performed on the basis of a contract of carriage to which the relevant provisions regulating the carriage of goods applied (UOKiK, 2009, p. 12). The justification for this position was Article 2 (2) (3) PLA 2003 with the same wording as the current Article 2 (2) (2) PLA 2012, providing that "The following shall not be a postal service (...) carriage of goods other than correspondence, performed under separate provisions" (UOKiK, 2009, p. 10).

The introduction of the definition of "courier item" to the Postal Law Act 2012 resulted in a change in the postal market. Operators who previously provided all courier services under the Transport Law Act have changed their general terms and conditions. Courier services relating to items of correspondence and postal parcels are usually currently provided on the basis of the provisions of the Postal Law Act $2012 .{ }^{11}$ If the service concerns an item that does not contain correspondence and does not meet the requirements of a postal parcel, then the provisions of the Transport Law Act apply. An example of such an approach is the Rules of Service Providing in Domestic Trade by DPD Strefa Paczki sp. z 0.0.12 According to the provision of $§ 2$ (1) of the Rules "DPD SP provides transport services or postal courier services ("services") with a guarantee of delivery time throughout the Republic of Poland". Courier services are provided on the basis of the Postal Law Act 2012 in respect of items containing correspondence or postal parcels ( $\$ 2$ (2) of the Rules). Transport services under the Transport Law Act are provided with respect to other items ( $\$ 2$ (4) of the Rules). Similar solutions are to be found in the rules of other leading courier companies. ${ }^{13}$

However, a question can be asked whether the provisions of the Postal Law Act 2012 forced such a decision on operators or left them a choice. Is it still allowed to provide courier services on the basis of transport law, despite the new Postal Law Act 2012? There is no doubt that the answer to this question is positive. Although the legislator introduced an indirect definition of courier service in the Act, it did not order that such service had to be provided on the basis of the Postal Law Act 2012. The article which excludes from the regime of the Postal Law the carriage

\footnotetext{
9 The definition of "courier services" was included in the Act of 23 November 1990 on communications (Journal of Laws No. 86, item. as amended). Pursuant to Article 2 (7) of this Act courier services "shall be understood as (...) services other than universal services, consisting in accelerated transport and delivery of items on commercial basis within a guaranteed period of time".

10 OJ No. 130, item 1188 as amended.

11 This explains the significant increase in the volume of courier items and revenues from the provision of courier services in 2013 (Stolarczyk, Sylwestrzak, 2018, p. 119).

12 https://www.dpd.com.pl//nne/Regulaminy (14.11.2018).

${ }^{13}$ See e.g. Por. np. Rules of Service Providing by General Logistics Systems Poland Spółka z 0.0. (https://gls-group.eu/PL/pl/ regulamin, accessed on 14.11.2018); Rules of providing postal and transport services by InPost Express Sp. z 0.0. (https://inpost.pl/ regulaminy, accessed on 14.11.2018); Conditions of carriage for domestic services by FedEx Express (https://www.fedex.com/pl-pl/ domestic-conditions-of-carriage.html, accessed on 14.11.2018).
} 
of goods "under separate provisions" allows at the same time to perform courier services on the basis of these "separate provisions".

Under the current legislation, a number of situations can therefore be distinguished:

a) if the subject of the displacement is an item with correspondence, the service is provided by the operator on the basis of a contract for the provision of postal services, if the conditions of Article 3(19) are met; ${ }^{14}$

b) if the subject of the displacement is anything other than a postal item or a non-addressed printed form, a contract of carriage between the parties is concluded;

c) when the subject of the displacement is a postal item other than a recorded item or a postal parcel, then, depending on the will of the parties, a contract for the provision of postal services (however, it is not a courier service within the meaning of Article 3 (19) PLA 2012) or a contract of carriage may be concluded;

d) if the subject of the displacement is a recorded letter item (other than an item of correspondence) or a postal parcel, the parties may also choose whether to enter into a contract for the provision of postal service (and it may be a courier service within the meaning of Article 3 (19) PLA 2012) or a contract of carriage of goods.

The Postal Law Act 2012 therefore created the possibility of providing courier services on the basis of its provisions, but it did not eliminate the possibility of providing them on the same rules as previously.

\section{Conclusions}

From these remarks, it is not easy to draw a strict distinction between postal services and transport services. It is necessary to consider whether the exception resulting from Article 2 (2) (2) PLA 2012 is not too far-reaching. It allows to circumvent regulatory requirements and to perform outside the regime resulting from the Postal Law Act 2012 services, which in their essence do not differ from postal services. It seems that the transport of goods bearing the marking of an address and an addressee, provided collectively with at least one of the activities referred to in Article 2 (1) (1) PLA 2012 should in any case be considered as provision of postal services. Leaving the carrier with the choice of the legal basis for the services provided is not conducive to consumers, who do not know which contract they enter into, ${ }^{15}$ as well as the competition in the market.

\section{References}

Gaj, M., Laprus-Bałuka, T., Zaborowska, A. (2017). Prawo pocztowe. Komentarz. Warszawa: C.H. Beck.

Marcysiak, A., Pieniak-Lendzion, K., Lendzion, M. (2013). Usługi kurierskie na rynku usług logistycznych w Polsce. Zeszyty Naukowe Uniwersytetu Przyrodniczo-Humanistycznego w Siedlcach, 96, 29-38.

Radwański, Z., Zieliński, M. (2012). Stosowanie i wykładnia prawa cywilnego. In: M. Safjan (ed.), System Prawa Prywatnego. Prawo cywilne część ogólna, t. 1 (pp. 451-543). Warszawa: C.H. Beck.

Stolarczyk, A. (2014). Przegląd zmian w polskim Prawie pocztowym - pakiet regulacyjny 2012/2013 r. internetowy Kwartalnik Antymonopolowy i Regulacyjny, 2 (3), 73-85.

Stolarczyk, A., Sylwestrzak, M. (2018). Rynek usług pocztowych w latach 2012-2017. internetowy Kwartalnik Antymonopolowy i Regulacyjny, 1 (7), 118-148.

Syp, S. (2018). Komentarz do art. 2, 3 ustawy Prawo pocztowe. In: M. Chołodecki, A. Piszcz, T. Skoczny (eds.), Prawo pocztowe. Komentarz. Warszawa. C.H. Beck.

\footnotetext{
${ }^{14}$ However, if these conditions are not met, we are in the situation of another postal service.

15 This was also highlighted under the PLA 2003 (UOKiK, 2009).
} 
UKE (Urząd Komunikacji Elektronicznej) (2018). Raport o stanie rynku pocztowego w 2017 roku. Warszawa.

UOKiK (Urząd Ochrony Konkurencji i Konsumentów) (2009). Raport z kontroli wzorców umownych stosowanych przez firmy kurierskie. Warszawa

Cite this article aS: Dąbrowski, D. (2018). Postal service, transport service, courier service - a few remarks in the context of the Postal Law Act 2012. European Journal of Service Management, 4 (28/1), 71-78. DOI: 10.18276/ejsm.2018.28/1-09. 